\title{
Erratum to: \\ Measurements of Thin Layers After the Coating Process
}

\author{
H. Frey and T. Hellmuth
}

\section{Erratum to: \\ Chapter 12 in: H. Frey, H. R. Khan, Handbook of Thin-Film Technology, 10.1007/978-3-642-05430-3}

Chapter 12: One of the author's names was misprinted. The author list should be read as: H. Frey and T. Hellmuth.

Following figures have been previously published: $12.28,12.29,12.33,12.35,12.36,12.39,12.40$, $12.41,12.42,12.43$. Permission for reuse has been granted and credits must be given as follow: Thomas G. Brown (Editor), Katherine Creath (Editor), Herwig Kogelnik (Editor), Michael Kriss (Editor), Joanna Schmit (Editor), Marvin J. Weber (Editor): The Optics Encyclopedia: Basic Foundations and Practical Applications, 5 Volumes Set. Page(s) 1469-1531. Publication year 2014. Copyright Wiley-VCH Verlag GmbH \& Co. KGaA. Reproduced with permission. 